\title{
ANTIFUNGAL POTENTIAL OF EXTRACTS AND FRACTIONS OF Randia nitida LEAVES ON SOYBEAN PATHOGENS AND THEIR PHYTOCHEMISTRY ${ }^{1}$
}

\author{
STHEFANY CAROLINE BEZERRA DA CRUZ-SILVA ${ }^{2 *}$, ROSEMARY MATIAS ${ }^{2}$, JOSÉ ANTONIO MAIOR BONO ${ }^{3}$, \\ KAREN SILVA SANTOS ${ }^{4}$, JULIANE LUDWIG ${ }^{5}$
}

\begin{abstract}
This study aimed to evaluate the antifungal activity of methanol extract and fractions of leaves of Randia nitida (Kunth) DC on Colletotrichum truncatum (Schw.) Andrus \& Moore, Rhizoctonia solani Kühn and Sclerotinia sclerotiorum (Lib.) De Bary and perform chemical and antioxidant activity tests. Crude methanol extract $(\mathrm{EBM})$ and fractions (hexane $=$ FHX, dichloromethane $=$ FDM and ethyl acetate $=$ FAE) underwent classical phytochemical analysis and determination of total phenols, flavonoids and antioxidant activity. Samples were individually incorporated into PDA culture mediums (potato-dextrose-agar) at concentrations of $10,20,40,80$ and $160 \mu \mathrm{g} \mathrm{mL} \mathrm{mL}^{-1}$ of extract or fraction. Mycelial growth was evaluated when control reached the edge of the plate. Phytochemical results indicated that flavonoids, steroids and triterpenoids are the major chemical constituents in both EBM and fractions. Total phenols, flavonoids and antioxidant activity were higher for FAE and EBM, followed by FDM and FHX; however, the latter showed higher content of steroids and triterpenoids compared to the other fractions. For C. truncatum, R. solani and S. sclerotiorum, the most efficient fractions were respectively FAE, FDM and FHX, all of them in the highest concentration $\left(160 \mu \mathrm{g} \mathrm{mL} \mathrm{m}^{-1}\right)$. The highest inhibition rate was observed against $S$. sclerotiorum, reaching $93.75 \%$. We concluded that all fractions have antifungal activity on the plant pathogens, being FHX the most active against $S$. sclerotiorum, which might have been due to the presence of steroids and triterpenes.
\end{abstract}

Keywords: Alternative control. Sclerotinia sclerotiorum. Rhizoctonia solani. Colletotrichum truncatum. Secondary metabolites. DPPH.

\section{POTENCIAL ANTIFÚNGICO DE EXTRATOS E FRAÇÕES DE Randia nitida SOBRE FITOPATÓGENOS DA SOJA E FITOQUIMICA}

\begin{abstract}
RESUMO - Objetivou-se neste estudo avaliar a atividade antifúngica do extrato metanólico e frações das folhas de Randia nitida (Kunth) DC. sobre Colletotrichum truncatum (Schw.) Andrus \& Moore, Rhizoctonia solani Kühn e Sclerotinia sclerotiorum (Lib.) de Bary e realizar análise química e atividade antioxidante. O extrato metanólico bruto $(\mathrm{EBM})$ e frações (hexânica $=\mathrm{FHX}$, diclorometano= FDM e acetato de etila $=\mathrm{FAE}$ ) foram submetidas a análise fitoquímica clássica e determinado os fenóis totais, flavonoides e atividade antioxidante. As amostras foram incorporadas, individualmente, ao meio de cultura BDA (batata-dextrose-ágar) nas concentrações de: 10, 20, 40, 80 e $160 \mu \mathrm{g} \mathrm{mL} \mathrm{mL}^{-1}$ de extrato ou fração. O crescimento micelial foi avaliado quando a testemunha alcançou a borda da placa. Os resultados fitoquímicos indicaram que os flavonoides, esteroides e triterpenos são os constituintes químicos majoritários no EBM e nas frações. O teor de fenóis totais, flavonoides e a atividade antioxidante foi maior para a fração FAE e extrato EBM, seguido da fração FDM e da FHX, contudo a fração hexânica apresentou maior conteúdo de esteroides e triterpenos em relação as demais frações. Para os três fungos, as frações eficientes foram as frações FAE, FDM e FHX, respectivamente, todas na maior concentração estudada $\left(160 \mu \mathrm{g} \mathrm{mL}^{-1}\right)$. A maior porcentagem de inibição foi observada frente ao patógeno S. sclerotiorum, chegando a 93,75\%. Conclui-se que todas as frações apresentam atividade antifúngica sobre os fitopatógenos e a fração FHX foi a mais ativa frente a Sclerotinia sclerotiorum, provavelmente pela presença de esteroides e triterpenos.
\end{abstract}

Palavras-chave: Controle alternativo. Sclerotinia sclerotiorum. Rhizoctonia solani. Colletotrichum truncatum. Metabólitos secundários. DPPH.

\footnotetext{
*Corresponding author

${ }^{1}$ Received for publication in $11 / 14 / 2014$; accepted in 04/06/2016.

Paper extracted from the master thesis of the first author.

${ }^{2}$ Post-graduate Program in Environment and Regional Development, Universidade Anhanguera - Uniderp, Campo Grande, MS, Brazil; sthefany.bcruz@gmail.com, rosematiasc@gmail.com.

${ }^{3}$ Post Graduate Program in Agro-industrial Production and Management, Universidade Anhanguera - Uniderp, Campo Grande, MS, Brazil; bono@uniderp.edu.br.

${ }^{4}$ Research Groupon Natural Products, Universidade Anhanguera - Uniderp, Campo Grande, MS, Brazil; karensantos02@hotmail.com.

${ }^{5}$ Agronomy Graduate Course, Universidade Federal da Fronteira Sul, Cerro Largo, SC, Brazil; juliane.ludwig@uffs.edu.br.
} 


\section{INTRODUCTION}

The Rubiaceae family deserves major attention within the wetlands of Mato Grosso do Sul state, in Brazil, due to its great diversity of species coupled with the lack of thorough studies on their practical applicability. Another feature emphasized on this botanical family is the wide variety of compounds produced by plants, including alkaloids, iridoids, flavonoids, terpenes and anthraquinones (SOUZA et al., 2013).

In this region, one of the most representative genus of that family is Randia, which stands out for displaying iridoid glycosides and triterpenoids as its main constituents (HAMERSKI et al., 2003). These metabolites are known for their various features, including antimicrobial activity (VIRTUOSO et al., 2005).

Among the species belonging to this genus, Randia nitida (Kunth) DC is a shrub known as indigoberry (ERBANO; DUARTE, 2011), which is regionally known as roseta (rosette) or veludo-deespinho (thorn velvet). This plant is considered a local pasture weed, being popularly used as antispasmodic (POTT; POTT, 1994). Its vegetative parts are applied in traditional medicine as wound healing and anti-inflammatory (ERBANO; DUARTE, 2011); nevertheless, there is no studies on its biological activity against microorganisms in literature.

Likewise Mato Grosso do Sul, the other states in the Midwestern Brazil are known, among other things, as major grain producers, which includes corn and soybean. The latter is one of the main oilseeds grown throughout this area are frequently subject to infections by several pathogens that can significantly increase production losses. For instance, it can be highlighted the fungi Sclerotinia sclerotiorum (Lib.) De Bary, causal agent of white mold; Rhizoctonia solani Kühn, etiologic agent of damping-off; and Colletotrichum truncatum (Schw.) Andrus \& Moore (synonym $C$. dematium var. truncata) agent of anthracnose (ALMEIDA et al., 2005). These diseases may affect all crop development stages, becoming key problems in areas of Brazilian Cerrado (a savannah-like environment) (ALMEIDA, 2005).

A proposed control strategy against these pathogens is commonly preventive practices. These techniques should primarily focus on soil physicalchemical conditions, such as crop rotation using nonhost species, no-tillage system, proper fertilizations, soil compaction reduction, avoiding cultivation in soaked soil, decrease number of plants per area and use of processed and/ or fungicide treated seeds (ALMEIDA et al., 2005). Conversely, chemical fungicides raise production costs, in addition to cause environmental, human and animal health problems derived from intensive and indiscriminate use (MEDICE et al., 2007).
The aforementioned factors encourage the search for effective and economically feasible alternatives for plant disease control, among which the use of plant extracts and essential oils with toxic active ingredients represents a natural defense mechanism involving secondary metabolites (ROZWALKA et al., 2008).

Based on this information and considering that $R$. nitida, a plant species commonly found in Mato Grosso do Sul wetlands, may present chemicals of antimicrobial potential; we aimed to evaluate the effect of its crude methanol extract and fractions (hexane, dichloromethane and ethyl acetate) at different concentrations on mycelial growth of $C$. truncatum, $R$. solani and $S$. sclerotiorum.

\section{MATERIAL AND METHODS}

Sampling of $R$. nitida leaves was conducted at a farm (Santa Emilia farm) located at $19^{\circ} 30^{\prime} 18^{\prime \prime} \mathrm{S}$ and $55^{\circ} 36^{\prime} 45^{\prime \prime} \mathrm{W}$, within the Pantanal (wetlands) of Aquidauana - MS, Brazil. One of the samples was herbalized and deposited at a herbarium under registration No. 7675, in the Laboratory of Anatomy and Plant Morphology of the University Anhanguera Uniderp, Campo Grande - MS, Brazil.

The leaves were dried in air oven at $40^{\circ} \mathrm{C}$ and then crushed. Subsequently, $780 \mathrm{~g}$ of this ground material were used to obtain crude methanolic extract (EBM) by extraction with methanol. The solvent was evaporated and to obtain the fractions of $7 \mathrm{~g}$ of EBM, it was subjected to partition with hexane (FHX), dichloromethane (FDM) and ethyl acetate (FAE). The partition was used targeting a semi-purification of substances through their polarities (SIMOES et al., 2010). The extract and fractions were used for chemical analysis and evaluation of in vitro antifungal activity.

Phytochemical analysis: For chemical challenge testing, EBM and fractions were subjected to wet chemical analysis of plant extracts through precipitation reactions and/ or color change, based on the method described by Matos (2009) and Costa (2002). The analyses were performed in three replicates and results were compared and contrasted observing color changing and precipitate formation (FONTOURA et al., 2015).

Confirmation of secondary metabolites and elution system were performed by thin layer chromatography (TLC: Silica gel $60 \quad \mathrm{~F}_{254}$ ), using specific reagents for terpenes, alkaloids, phenolic compounds, and flavonoids (WAGNER; BLADT, 2009).

Determination of total phenols: The total phenol content (TP) of EBM and fractions (FHX, FDM and FAE) was determined by the Folin-Ciocalteu's 
method using $100 \mathrm{mg}$ of each sample. TP was quantified using calibration regression equation $(\mathrm{y}=$ 0.0077x - 0.0228: $\left.\mathrm{R}^{2}=0.9985\right)$ against gallic acid standards (10 to $300 \mu \mathrm{g} \mathrm{mL} \mathrm{mL}^{-1}$ ). The analyses were performed in triplicate and means were calculated from standard deviation. The analyses were carried out using a spectrophotometer at wavelength of 750 $\mathrm{nm}$, by interpolation of sample absorbance using the calibration curve (SOUSA et al., 2007).

Determination of flavonoids: For quantification of flavonoids in EBM $(100 \mathrm{mg})$ and in fractions FHX, FDM and FAE (100 mg), we used a method adapted by Peixoto Sobrinho et al. (2008) that uses quercetin standard $\left(0.5 \mathrm{mg} \mathrm{mL}^{-1}\right)$ to build a calibration curve at the concentrations of $0.2,0.3,0.4,0.55,0.7$ and 0.8 $\mathrm{mg} \mathrm{mL} \mathrm{mL}^{-1}$. Again, the analyses were carried out by spectrophotometry at a wavelength of $420 \mathrm{~nm}$, in quartz cuvettes. Flavonoids were quantified using calibration regression equation $(\mathrm{y}=0.132+0.0353$ $\left.\mathrm{x}: \mathrm{R}^{2}=0.9949\right)$. These analyses were performed in triplicate and means were calculated from standard deviation.

Antioxidant activity: Antioxidant activity in EBM, FHX, FDM and FAE was determined by a qualitative and quantitative method. For qualitative analysis, solutions were prepared in $1 \mathrm{mg} \mathrm{mL}^{-1}$ in methanol/ ethanol (1:1) and, from these stock solutions, $10 \mu \mathrm{L}$ of each sample was applied on analytical TCL plates $\left(\mathrm{GF}_{254}\right.$ silica gel) (5.0 by 18.0 $\mathrm{cm}, 0.2 \mathrm{~mm}$, MERCK $\left.^{\circledR}\right)$. Elution was conducted with ethyl acetate for hexane (1:2) and with chloroform for methanol (1:1), and absorbance was measured with a methanol solution of DPPH (2,2-diphenyl-1picrylhydrazyl) at $0.2 \%$. A hallmark of antioxidant activity was the presence of white or yellow spots from reduced DPPH against a background of purple color (MENSOR et al., 2001).

The quantitative analysis of antioxidant potential was determined based on free radical scavenging activity of DPPH (SOUSA et al., 2007). Samples at concentrations of 250, 200, 150, 100, 50 and $25 \mathrm{mg} \mathrm{mL}^{-1}$ were added to $2 \mathrm{~mL}$ DPPH solution in methanol (24 mg $100 \mathrm{~mL}^{-1}$ of methanol). After 30 min, the absorbance was determined using a UV-VIS spectrophotometer at $515-\mathrm{nm}$ wavelength. DPPH solution in methanol was used as negative control and BHT (butylated hydroxytoluene) as positive control at the same concentrations used in the samples (THAIPONG et al., 2006). The percentage of free radical inhibition by DPPH $(\%$ I) was calculated using the following formula: $\% \mathrm{I}=\left(\mathrm{A}_{0}-\mathrm{A}\right) /$ $\mathrm{A}_{0}$ ), in which $\mathrm{A}_{0}$ is the absorbance of $\mathrm{DPPH}$ (control) and A is the sample absorbance plus DPPH.

Antifungal activity: Fungal isolates of Colletotrichum truncatum (CMM-221), Rhizoctonia solani (CMM-1243) and Sclerotinia sclerotiorum (CMM-7) were obtained from the Fungal Collection of the Laboratory of Phytopathology, University Anhanguera - Uniderp, collected from plant lesions in soybean and cotton fields. They were identified by structural analysis via light microscopy; after isolation, colonies were transferred to tubes with PDA medium and stored at $5^{\circ} \mathrm{C}$. Tests for antifungal activity in vitro used stock solutions separately prepared. These solutions had $0.05 \mathrm{~g}$ of each extract or fraction (EBM, FHX, FDM, and FAE) plus 5- $\mu \mathrm{L}$ dimethyl sulfoxide (DMSO) and were filled with $20 \%$ water-alcohol solution up to $100 \mathrm{~mL}$ volume. From each stock solution, an aliquot $(100,200,400$, 800 and $1600 \mu \mathrm{g}$ ) was apart incorporated into 100 $\mathrm{mL}$ melting PDA medium (Potato-Dextrose-Agar), thereby obtaining concentrations of $10,20,40,80$ and $160 \mu \mathrm{g} \mathrm{mL}^{-1}$.

Subsequently, samples in an amount of $10 \mathrm{~mL}$ of the solution at each concentration were poured into Petri dishes for solidification; then, $5 \mathrm{~mm}$ PDA discs of mycelial culture were transferred to the center of each plate, being placed in BOD incubators at $22 \pm 2{ }^{\circ} \mathrm{C}$ and a 12 hour photoperiod. As a control, we used plates containing only BDA and fungal mycelium. Evaluations were made when mycelial growth in control plates fully covered the medium surface; they consisted of measuring colony development (average of two diametrically opposed measures).

The fungal control was evaluated using a formula described by Bastos (1997) to calculate growth inhibition rate $(\mathrm{GI} \%)$ :

$$
G I \%=\frac{D c-D t}{D t} \times 100
$$

Wherein: Dc $=$ Mycelium diameter of control; Dt $=$ Mycelium diameter of the treatment.

Treatments were evaluated using a completely randomized experimental design in a $3 \times 4 \times 6$ factorial scheme (fungi $\mathrm{x}$ extract/ fraction $\mathrm{x}$ concentration) with four replications. Data underwent variance analysis and regression using the procedures PROC GLM and PROC REG of the SAS software (SAS, 1990). For regression analyses, models were fitted in terms of concentration and colony diameter according to each extract/ fraction, considering significant only regressions at 5\% probability. The model was chosen based on the estimates of parameters that had residual nearest zero.

\section{RESULTS AND DISCUSSION}

The results of the phytochemical screening of extracts and fractions of $R$. nitida leaves are listed in Table 1. Flavonoids, triterpenes and steroids were present in both EBM extract and all evaluated 
fractions, regardless of the polarity of the solvent used in chemical fractioning.

The major secondary metabolites present in the $R$. nitida leaves differed regarding contents of coumarin, triterpenes, alkaloids, saponins in a comparison with study of Vieira et al. (2005), who identified phenolic compounds, flavones, tannins, catechins, xanthones and steroids in ethanol extract of leaves sampled in the region of Ceará. The presence of secondary metabolites in the same plant species can be influenced by intrinsic and extrinsic factors such as environment, weather and topography, besides solvent type and extraction method (GOBBO-NETO; LOPES, 2007).

Table 1. Results of phytochemical analysis, quantification of total phenol and flavonoids and antioxidant potential of the Crude Methanol Extract (EBM) and the fractions of hexane (FHX), dichloromethane (FDM), ethyl acetate (FAE) of the $R$. nitida leaves sampled in the wetlands Pantanal (wetlands).

\begin{tabular}{|c|c|c|c|c|}
\hline \multirow[b]{2}{*}{ Secondary metabolites } & \multicolumn{4}{|c|}{ Extract/ Fractions } \\
\hline & EBM & FHX & FDM & FAE \\
\hline Phenolic compounds & +++ & - & +++ & +++ \\
\hline Tannins & +++ & - & - & ++ \\
\hline Flavonoids & +++ & + & ++ & +++ \\
\hline Coumarins & ++ & - & ++ & ++ \\
\hline Triterpenes & +++ & +++ & ++ & ++ \\
\hline Steroids & +++ & +++ & ++ & + \\
\hline Alkaloids & ++ & - & ++ & ++ \\
\hline${ }^{*}$ Saponins & + & - & - & + \\
\hline T.P. $=\left(m g\right.$ GAE g $\left.{ }^{-1} \pm \mathrm{SD}\right)$ & $524.52 \pm 0.46$ & $118.34 \pm 1.09$ & $332.25 \pm 0.89$ & $575.27 \pm 0.02$ \\
\hline $\mathrm{T} . \mathrm{F} .=\left(\mathrm{mg} \mathrm{QE} \mathrm{g}{ }^{-1} \pm \mathrm{SD}\right)$ & $178.47 \pm 0.98$ & $28.15 \pm 0.46$ & $48.54 \pm 0.44$ & $245.28 \pm 0.08$ \\
\hline A.A. $\left[\mathrm{EC}_{50}\left(\mu \mathrm{g} \mathrm{mL}^{-1}\right)\right]$ & $170.14 \pm 0.04$ & $30.67 \pm 0.09$ & $77.56 \pm 0.11$ & $214.82 \pm 0.12$ \\
\hline
\end{tabular}

Crude methanol extract $=$ EBM; Hexane fraction $=$ FHX; Dichloromethane fraction $=$ FDM; Ethyl acetate fraction $=$ FAE. *Dry matter analysis. Lower intensity $=(+)$, medium intensity $=(++)$, higher intensity $=(+++)$, negative $=(-)$. T.P. $=$ total phenols; GAE $=$ gallic acid equivalent; T.F. $=$ total flavonoids; $\mathrm{QE}=$ quercetin equivalent; A.A. = antioxidant activity: $\mathrm{EC}_{50}=$ concentration sufficient to obtain $50 \%$ of the maximum ability to scavenge free radicals.

In the literature, studies report several compounds isolated from other species of the genus Randia, such as coumarin from leaves of R. nilotica; triterpenes and coumarins from $R$. longiflora and $R$. longispina; triterpenoid saponins, and flavonoids from $R$. formosa and flavonoids; and triterpenoid saponins, coumarins, steroids and mannitol (sugar) from $R$. hebecarpa (HOSTETTMANN et al., 2000; NAZARI et al., 2006).

Regarding alkaloids, no studies were found mentioning such class of secondary metabolite for leaves of other species of Randia. Studies by SotoSobenis et al. (2001) identified alkaloids in 234 species of the Rubiaceae family in a herbarium in Panama, which may explain the presence of these metabolites in $R$. nitida.

The results of total phenols and flavonoids measurements, in Table 1, demonstrate a higher concentration of these constituents in FAE, followed by EBM, FDM and FHX. This outcome also justifies the higher antioxidant activity in FAE. In addition, the same amount of phenolic compounds, flavonoids, coumarins, alkaloids and saponins were found in both FAE and EBM. In the TLC analysis, the antioxidant activity of FAE became apparent in plates when compared to the standard (quercetin = flavonoid).

According to the variance analysis, we can observe a significant interaction between extract/ fraction and concentrations. Moreover, FAE and FDM provided a significant reduction in $C$. truncatum colony diameter, being major at the highest concentration for both fractions, which reached 21.5 and $16.7 \%$ reduction, respectively (Figure 1).

Similar inhibition percentages were reported by Celoto et al. (2008) using extracts of mamona (Ricinus communis), bucha (Luffa acutangula), mentrasto (Peltodon radicans) and arruda (Ruta graveolens) on $C$. gloeosporioides mycelial growth. MONTRUCCHIO et al. (2005) evaluated the antifungal activity of marapuama extract (Ptychopetalum olacoides) identified 60\% inhibition on $C$. acutatum and $38 \%$ on Fusarium oxysporum. The ethyl acetate fraction of acacia (Acacia longifolia), had inhibitory effect of $15.09 \%$ on $C$. acutatum, $30 \%$ on Rhizoctonia sp. and $10.5 \%$ on $F$. oxysporum (KERBER; SILVA, 1993). 


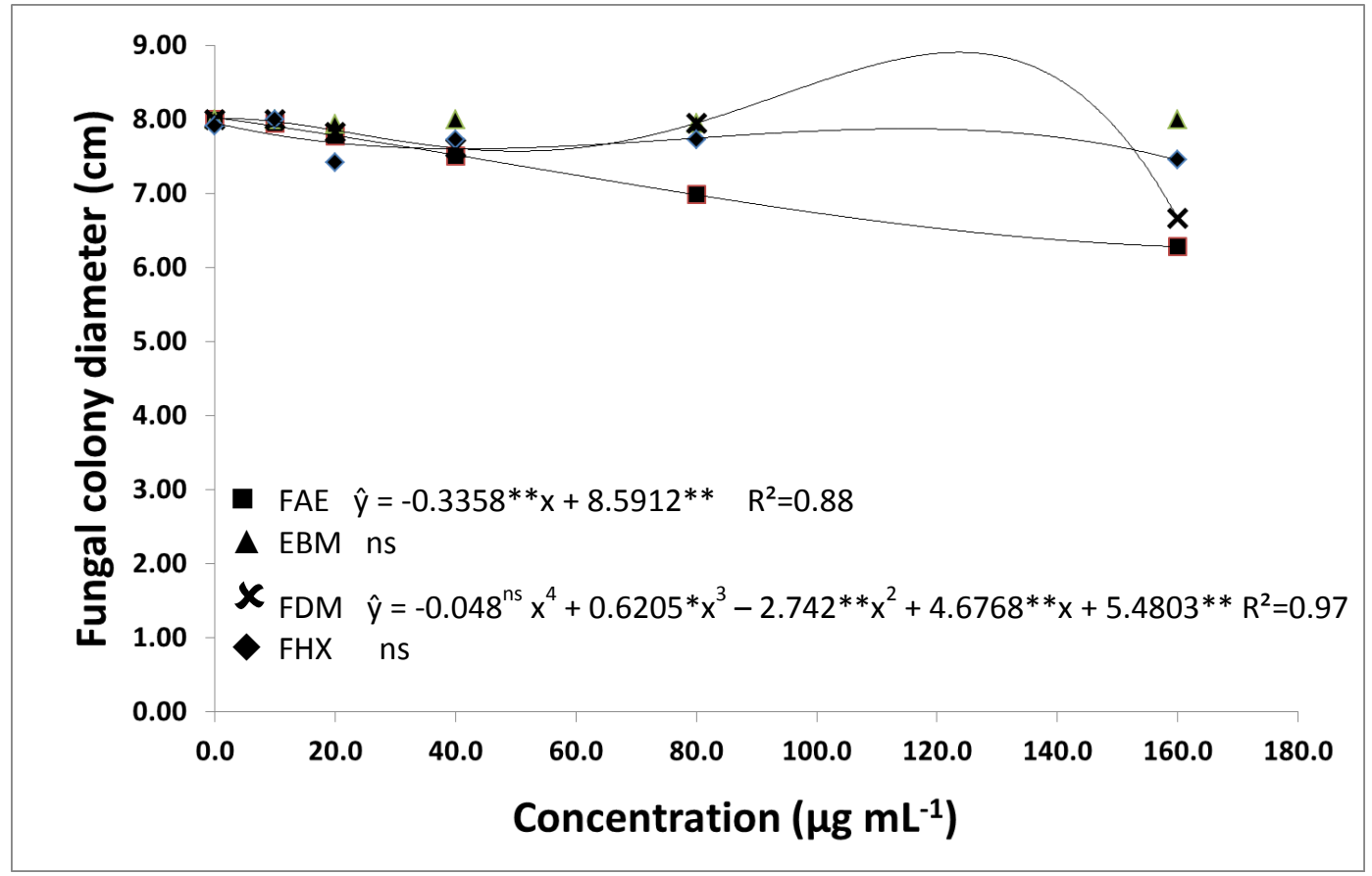

Figure 1. Inhibition of the $C$. dematium var. truncata colony diameter $(\mathrm{cm})$ against different concentrations extract/ fractions of R. nitida leaves (EBM: crude methanol extract, FHX: hexane fraction, FDM: dichloromethane fraction, FAE: ethyl acetate fraction).

Mycelial growth inhibition was observed using FAE compared to the control at all concentrations used. For concentrations of 40 and 80 $\mu \mathrm{g} \mathrm{mL} \mathrm{m}^{-1}$, an increasing trend was observed in mycelial growth compared to the preceding one (20 $\left.\mu \mathrm{g} \mathrm{mL}^{-1}\right)$; however, at the highest concentration (160 $\left.\mu \mathrm{g} \mathrm{mL}^{-1}\right)$, mycelial growth declined further, equating to the concentration of $20 \mu \mathrm{g} \mathrm{mL}^{-1}$ (Figure 2).

With respect to $R$. solani, we noted that only EBM did not inhibit fungal growth (Figure 2); nonetheless, higher inhibition values were observed in all fractions, highlighting the concentration of 160 $\mu \mathrm{g}$ with $16.1,37.6$ and $37.2 \%$ for FHX, FDM and FAE, respectively.

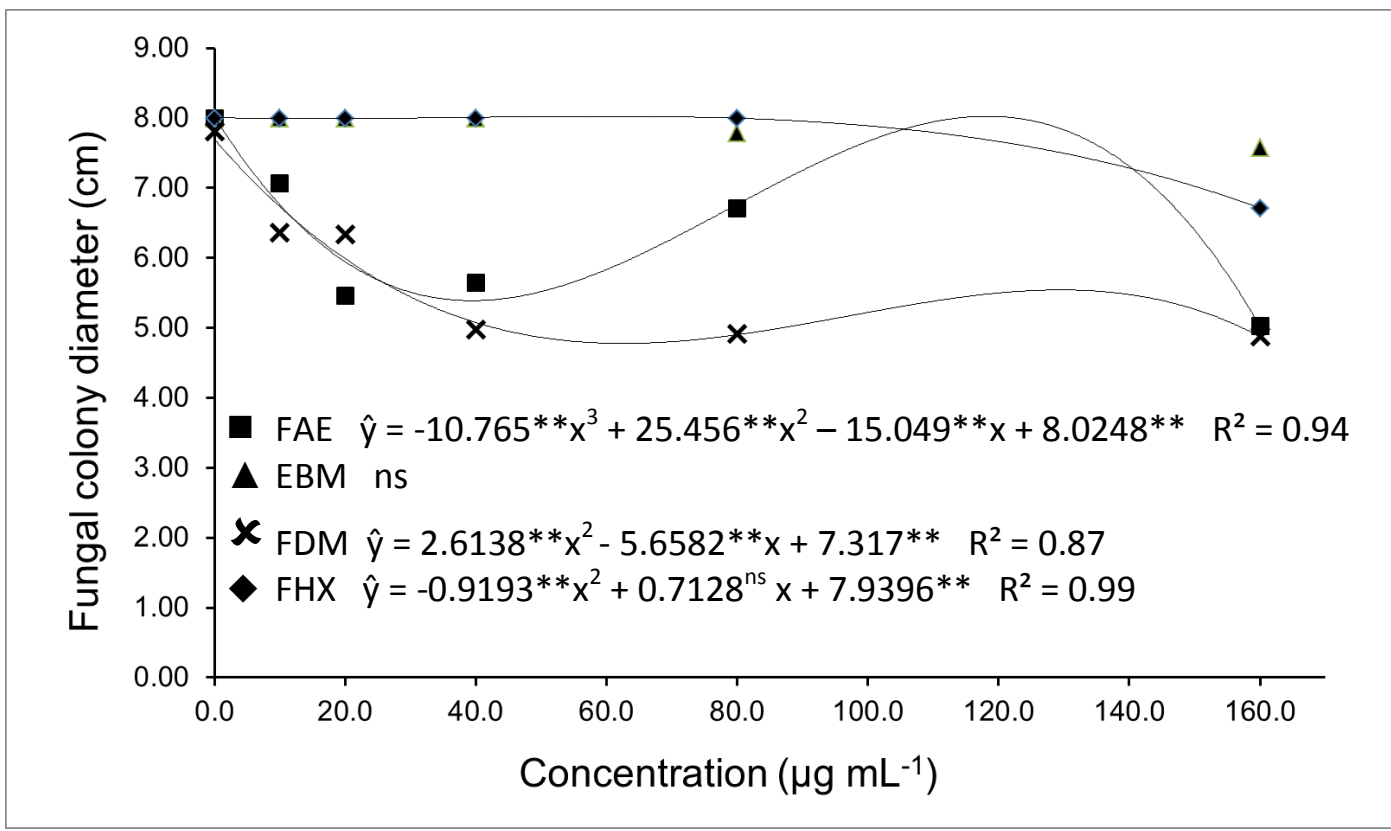

Figure 2. Inhibition of the Rhizoctonia solani colony diameter $(\mathrm{cm})$ against different concentrations of extract/ fractions of $R$. nitida leaves. (EBM: crude methanol extract, FHX: hexane fraction, FDM: dichloromethane fraction, FAE: ethyl acetate fraction).

The effect of plant extracts against pathogens is main target for several studies of different research

groups in order to justify their fungicidal effect. In general, it is expected that synthetic molecule 
actions, particularly as fungicides, have major fluctuations in concentrations; for if the absorption and distribution were instantaneous and linear, such fluctuations would be fully related to the active ingredient half-life. Higher concentrations are often easily tolerated by a target pathogen; on the other hand, a narrow therapeutic range has greater absorption power, therefore being most active. For this reason, it is important to estimate both maximum and minimum concentrations that have fungicide effect (BRUTON et al., 2012). This information justifies the findings in our research for FAE action, which showed inhibition peaks at different concentrations, whereas the concentration of $20 \mu \mathrm{g}$ $\mathrm{mL}^{-1}$ would be suitable for applications in other assays.

Similar results of higher inhibition at lower concentrations were also reported by Rodrigues et al. (2006) when using aqueous crude extracts of gengibre (Zinziber officinalis) and eucalipto (Corymbia citriodora) on Helminthosporium sp. from banana fibers. These authors found that $50 \mu \mathrm{g}$ $\mathrm{mL}^{-1}$ ginger extract had already reduced mycelial growth; however, in higher concentrations $(100,200$, and $400 \mu \mathrm{g} \mathrm{mL}^{-1}$ ) inhibition decreased. However, eucalyptus extract inhibition remained constant; the authors observed that the greater inhibitory effect occurred at a concentration of $322.5 \mu \mathrm{g} \mathrm{mL}{ }^{-1}$, with discrete mycelial growth occurring on higher concentrations (from 32.26 to $40 \%$ ).

We also observed that FAE inhibited up to $37.2 \%$ mycelial growth at a concentration of $160 \mu \mathrm{g} \mathrm{mL}^{-1}$. Similarly, Fiori et al. (2000) found that mil-folhas essential oil (Achillea millefolium) at a concentration of $20 \mu \mathrm{L}$ achieved similar inhibition percentage $(35.02 \%)$.

Mycelial growth inhibition stabilized in FDM at concentrations above $40 \mu \mathrm{g} \mathrm{mL}^{-1}$, indicating that control level is not increased in higher concentrations of this extract, reaching an average inhibition of $37.0 \%$. In FHX, the onset of mycelial growth inhibition occurred at the highest concentration, reaching $16.1 \%$, which indicates the need to evaluate even higher concentrations (Figure 2).

Silveira et al. (2003), when assessing the fungicidal effect of Captan at a concentration of $1 \mu \mathrm{g}$ $\mathrm{mL}^{-1}$ (1 ppm), obtained mycelial growth inhibition of $R$. solani in a percentage lower than in this study. It is noteworthy mention that even if higher doses are required to achieve similar effects, we used fractions from a native plant crude extract, which is biodegradable and less toxic to the environment.

For the fungus $S$. sclerotiorum, the only treatment that inhibited mycelial growth was FHX, with a significant reduction in colony diameter in the first few tested concentrations. The level of control at the concentration of $160 \mu \mathrm{g} \mathrm{mL}^{-1}$ reached $93.8 \%$ (Figure 3)

This inhibition percentage is greater than that obtained by Diniz et al., (2008), who used essential oil of hortelã-doce (Mentha arvensis), as well as azadirachtin at the concentration of $100 \mu \mathrm{g}$ a.i. $\mathrm{mL}^{-1}$ with 1/3 karanja oil (GARCIA et al., 2012) compared to the same pathogen. Another species of the genus Sclerotinia showed sensitivity to FHX substances, the germination of sclerotia of the fungus $S$. rolfsii were totally inhibited by hexane extracts of Ruta graveolens and Impatiens walleriana (DOMINGUES et al., 2009).

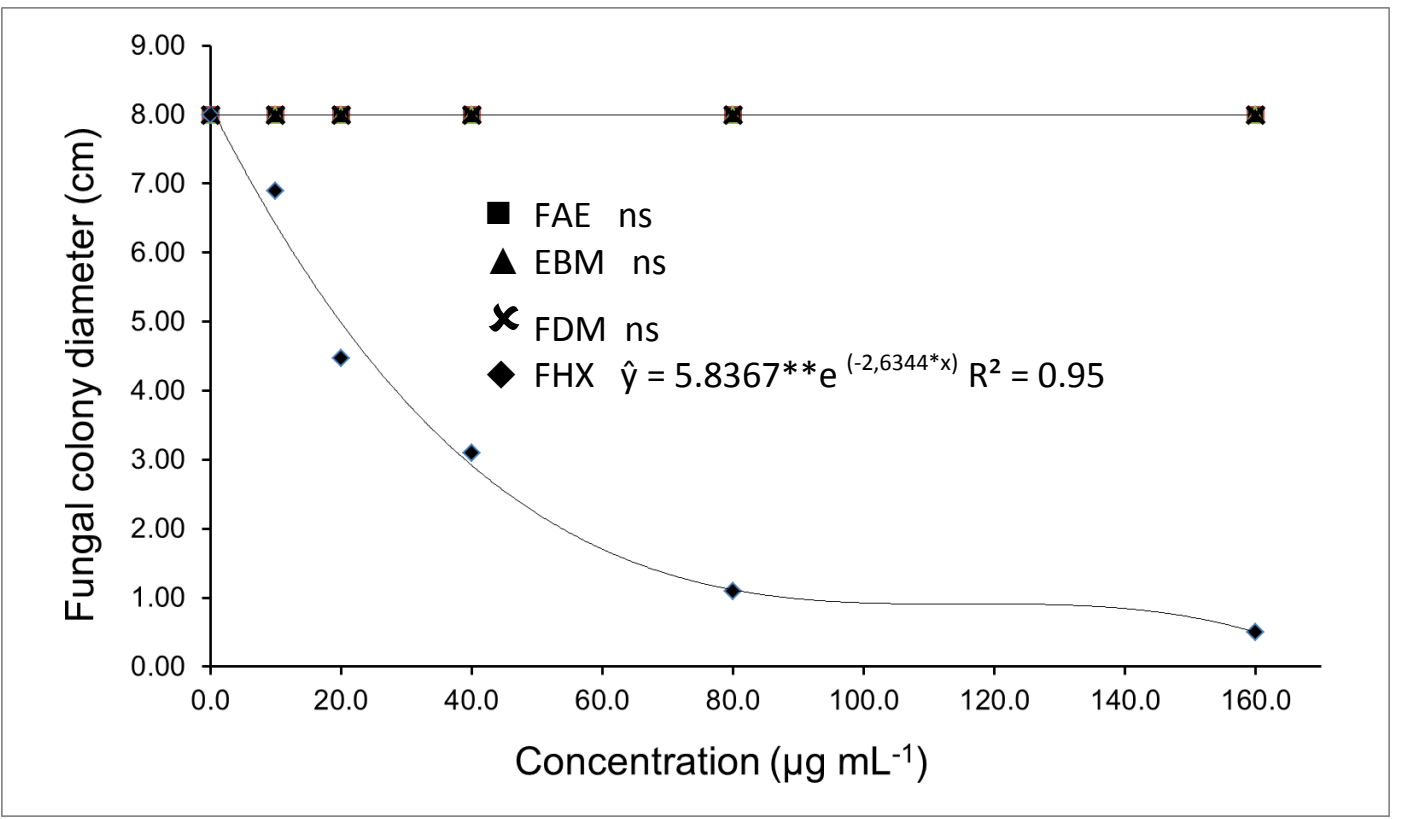

Figure 3. Inhibition of the Sclerotinia sclerotiorum colony diameter $(\mathrm{cm})$ against different concentrations of extract/ fractions of $R$. nitida leaves. (EBM: crude methanol extract, FHX: hexane fraction, FDM: dichloromethane fraction, FAE: ethyl acetate fraction). 
Flavonoids, steroids and triterpenoids were detected in the hexane fraction (FHX). These metabolites are recognized for presenting various activities, including antimicrobial action (VIRTUOSO et al., 2005). Triterpenoid glycosides have been found in other species of the genus Randia with other biological activities (SAHPAZ et al., 2000). Therefore, in this study, the activity of this fraction can be attributed to steroids and triterpenes, since they are often found in this fraction compared to the others. However, as FDM extract also showed high frequency of these metabolites, its low fungicide potential might be related to an antagonistic effect of the other classes present.

Steroids and triterpenes are two classes of secondary metabolites with non-polar and medium polar characteristics, but the basic skeleton is nonpolar (SIMOES et al., 2010). These are important features acting on fungal cell membrane and affect its permeability and, consequently, causing membrane distortion; thus, cell malfunction occurs by a leakage of essential metabolites, which are important cell components (HARAGUCH et al., 1999; PERUMAL; GOPALAKRISHNAKONE, 2010).

The positive effects shown by using $R$. nitida extract as control alternative are quite interesting; since in cases of absence of soybeans variety resistant to $S$. sclerotiorum as well as fungicide resistance in this pathogen population (GOSSEN et al., 2001; LI et al. 2003;), this product can be used in the management of this disease.

However, through the analyses, although these fractions (FHX, FDM and FAE) derive from crude methanol extract (EBM), the latter did not show significant inhibition of the fungi studied, regardless of high levels of total phenols, flavonoids and antioxidant activity found in it (Table 1). It is clear that sort of an antagonism must exist, once when gathered in the crude extract, the fractions (containing their respective metabolites) show no activity, being necessary their separation so they can present any activity.

The fact that a plant extract presents several classes of secondary metabolites may enable antagonistic interactions among its various phytoconstituents; hence, results are most often misinterpreted due to a masking effect on bioavailability of the major constituents and chemotaxonomic plant markers (SIMOES et al., 2010). It is worth noting that chemical fractioning by partition is used for semi-purification of substances through their polarities (SILVA et al., 2013). Based on this information, one can point out that methanol (solvent extractor) has an ability to extract polar substances, with medium polarity and non-polar. Moreover, depending on the concentration of such groups, especially those with higher polarity (hydrophilic), these chemical constituents do not easily affect cell wall permeability.

According to Singh and Barrett (2006), in recent years, fungal cell wall emerged as a very important target to detect selective antifungal agents. Given that, FAE, which has shown to be most active, has chemical groups with medium polarity that may interact easily with fungus cell wall (SIMOES et al., 2010). Studies reporting antagonistic effects with plant extracts and fractions, which are able to inhibit growth of pathogens in vitro, are still incipient. Véras et al. (2002) reported Piper aduncum L. extract and essential oil antagonistic activity against Ralstonia solanacearum growth, demonstrating that antagonistic effect of phytochemicals may also occur with botanical extracts.

\section{CONCLUSIONS}

The extracts FHX, FDM and FAE of Randia nitida leaves have antifungal action against the studied plant pathogens (Colletotrichum truncatum, Rhizoctonia solani and Sclerotinia sclerotiorum). This activity may be related to their major constituents such as flavonoids, steroids and triterpenes, which were detected in EBM extract and in all three fractions. While other classes as phenolic compounds, tannins, coumarins, alkaloids and saponins, present in the EBM, did not have the same distribution in the fractions. FHX was the most active against Sclerotinia sclerotiorum, what may be related to the presence of triterpenes and steroids.

\section{ACKNOWLEDGEMENTS}

The authors want to acknowledge the Coordenação do Aperfeiçoamento do Pessoal do Ensino Superior - CAPES (Coordination for the Improvement of Higher Education Personnel CAPES) for providing $\mathrm{PhD}$ scholarship by the PROSUP (Program of Post-Graduation Support) and Pesquisador $\mathrm{CNPq}$ 2. We also thank for financial support by the Conselho Nacional de Desenvolvimento Científico e Tenológico - CNPq (National Council for Scientific and Technological Development - CNPq), the Centro de Pesquisa do Pantanal - CPP (Research Center of the Brazilian Wetlands - CPP), the Instituto Nacional de Áreas Úmidas - INAU (National Office of Wetlands INAU), the Fundação de Apoio ao Desenvolvimento do Ensino e a Ciência e Tecnologia do Estado de Mato Grosso do Sul - FUNDECT (Foundation of Support for Education, Science and Technology of the Mato Grosso do Sul state - FUNDECT) and the Universidade Anhanguera - Uniderp (Anhanguera University - Uniderp). 


\section{REFERENCES}

ALMEIDA, A. M. R. et al. Doenças da Soja. In: KIMATI, H. et al. (Eds.) Manual de Fitopatologia: doenças das plantas cultivadas. São Paulo: Ceres, 2005. 4. ed., v. 2, cap. 61, p. 596-617.

BASTOS, C. N. Efeito do óleo de Piper aduncum sobre Crinipelis e outros fungos fitopatogênicos. Fitopatologia Brasileira, Lavras, v. 22, n. 3, p. 4413, 1997

BRUTON, L. L. et. al. As Bases Farmacológicas da Terapêutica de Goodman \& Gilman. 12. ed. São Paulo, SP: McGraw-HillInter Americana do Brasil, 2012. 2112 p.

CELOTO, M. I. B. et al. Atividade antifúngica de extratos de plantas a Colletotrichum gloeosporioides. Acta Scientiarum Agronomy, Maringá, v. 30, n. 1, p. 1-5, 2008.

COSTA, A. F. Farmacognosia. 6. ed. Lisboa: Calouste Gulbenkian, 2002. 824 p.

DINIZ, S. P. S. S. et al. Bioatividade do óleo essencial de Mentha arvensis L. no controle de fitopatógenos. Revista Brasileira de Plantas Medicinais, Botucatu, v. 10, n. 4, p. 9-11, 2008.

DOMINGUES, R. J. et al. Ação “in vitro" de extratos vegetais sobre Colletotrichum acutatum, Alternaria solani e Sclerotium rolfsii. Arquivos do Instituto Biológico, São Paulo, v. 76, n. 4, p. 643649, 2009.

ERBANO, M.; DUARTE, M. R. Macro and microscopic analysis of the leaf and stem of Randia armata (Sw.) DC., Rubiaceae. Latin American Journal of Pharmacy, Buenos Aires, v. 30, n. 6, p. 1239-1243, 2011.

FIORI, A. C. G. et al. Antifungal activity of leaf extracts and essential oils of some medicinal plants against Didymella bryoniae. Journal Phytopathology, Salinas, v. 148, n. 7-8, p. 483-487, 2000.

FONTOURA, F. M. et al. Seasonal effects and antifungal activity from bark chemical constituents of Sterculia apetala (Malvaceae) at Pantanal of Miranda, Mato Grosso do Sul, Brazil. Acta Amazonica, Manaus, v. 45, n. 3, p. 283-292, 2015.

GARCIA, R. A. et al. Atividade antifúngica de óleo e extratos vegetais sobre Sclerotinia sclerotiorum. Bioscience Journal, Uberlândia, v. 28, n. 1, p. 4857, 2012.

GOBBO-NETO, L.; LOPES, N. P. Plantas medicinais: fatores de influência no conteúdo de metabólitos secundários. Química Nova, São Paulo, v. 30, n. 22, p 374-381, 2007.

GOSSEN, B. D. et al. First report of resistance to benomyl fungicide in Sclerotinia sclerotiorum. Plant Disease, Ames, v. 85, n. 11, p. 1206, 2001.

HAMERSKI, L. et al. Iridoid glycosides from Randia spinosa (Rubiaceae). Phytochemistry, Maryland Heights, v. 63, n. 4, p. 397-400, 2003.

HARAGUCHI, $H$. et al. Antimicrobial triterpenes from Ilex integra and the mechanism of antifungal action. Phytotherapy Research, England, v. 13, n. 2, p. 151-156, 1999.

HOSTETTMANN, K.; SAHPAZ, S.; GUPTA, M. P. Triterpene saponins from Randia formosa. Phytochemistry, Maryland Heights, v. 54, n. 1, p. 77-84, 2000.

KERBER, V. A.; SILVA, G. A. A. B. Flavonóides da Acacia longifolia (Andr) Willd-LeguminosaeMimosoideae. Revista Brasileira de Farmácia Maringá, v. 74, n. 1, p. 16-18, 1993.

LI, G. Q. et al. Antagonism and biocontrol potential of Ulocladium atrum on Sclerotinia sclerotiorum. Biological Control, Maryland Heights, v. 28, n. 1, p. 11-18, 2003.

MATOS, F. J. A. Introdução a fitoquímica experimental. 3. ed. Fortaleza, CE: Edições UFC, 2009. 150p.

MEDICE, R. et al. Óleos essenciais no controle da ferrugem asiática da soja Phakopsora pachyrhizi Syd. \& P. Syd. Ciência Agrotecnologia, Lavras, v. 31, n. 1, p. 83-90, 2007.

MENSOR, L. L. et al. Screening of Brazilian plant extracts for antioxidant activity by the use of DPPH free radical method. Phytotherapy Research, Londres, v. 15, n. 2, p. 127-130, 2001.

MONTANARI, C. A.; BOLZANI, V. S. Planejamento racional de fármacos baseado em produtos naturais. Quimica Nova, São Paulo, v. 24, n. 1, p. $105-11,2001$.

MONTRUCCHIO, D. P. et al. Componentes químicos e atividade antimicrobiana de Ptychopetalum olacoides Bentham. Visão Acadêmica, Curitiba, v. 6, n. 2, p. 48-52, 2005.

NAZARI, A. S. et al. Anti-inflammatory and antioxidant activities of Randia hebecarpa and major constituents. Pharmaceutical Biology, Thyagaraja Nagar, v. 44, n. 1, p. 7-9, 2006. 
PERUMAL, S. R.; GOPALAKRISHNAKONE, P. Therapeutic potential of plants as anti-microbials for drug discovery. Evidence-based complementary and alternative medicine, Cairo, v. 7, n. 3, p. 283294, 2010.

PEIXOTO SOBRINHO, T. J. S. et al. Validação de metodologia espectrofotométrica para quantificação dos flavonóides de Bauhinia cheilantha (Bongard) Steudel. Revista Brasileira de Ciências Farmacêuticas, São Paulo, v. 44, n. 4, p. 683-689, 2008.

POTT, A.; POTT, V. J. Plantas do pantanal. 1. ed. Brasília, DF: EMBRAPA-CPAP, 1994. 320 p.

RÍOS, J. L. et al. Antimicrobial activity of selected plants employed in the Spanish Mediterranean area. Journal of Ethnopharmacology, Maryland Heights, v. 21, n. 2, p. 139-152, 1987.

RODRIGUES, E. et al. Avaliação da atividade antifúngica de extratos de gengibre e eucalipto in vitro e em fibras de bananeira infectadas com Helminthosporium sp. Acta Science Agronomy, Maringá, v. 28, n. 1, p. 123-127, 2006.

ROZWALKAI, L. C. et al. Extratos, decoctos e óleos essenciais de plantas medicinais e aromáticas na inibição de Glomerella cingulata e Colletotrichum gloeosporioides de frutos de goiaba. Ciência Rural, Santa Maria, v. 38, n. 2, p. 301-307, 2008.

SAS USER's GUIDE: Statistics. 6. ed. Cary: SAS Institute, $1990.846 \mathrm{p}$.

SILVEIRA, S. F. da et al. Controle químico da queima de folhas e da mela de estacas de eucalipto, causadas por Rhizoctonia spp. Fitopatologia Brasileira, Brasília, v. 28, n. 6, p. 642-649, 2003.

SILVA et al. Crude extracts and semi-fractions from Myracrodruon urundeuva with antibacterial activity against American type culture collection (ATCC) strains of clinical relevance. Journal of Medicinal Plants Research, Nsukka, v. 7, n. 32, p.2407-2413.

SIMÕES, C. M. O. et al. Farmacognosia: da planta ao medicamento. 6. ed. Porto Alegre/Florianópolis, SC: Editora UFRGS/UFSC, 2010. 1104 p.

SINGH, S. B.; BARRETT, J. F. Empirical antibacterial drug discovery-foundation in natural products. Biochemical pharmacology, Kansas, v. 71, n. 7, p. 1006-1015, 2006.

SOTO-SOBENIS, A. et al. Screening of Herbarium Samples of Rubiaceae from Panama. Pharmaceutical Biology, Thyagaraja Nagar, v. 39, n. 3, p. 161-169, 2001.

SOUSA, C. M. M. Fenóis totais e atividade antioxidante de cinco plantas medicinais. Química Nova, São Paulo, v. 30, n. 2, p. 351-355. 2007.

VÉRAS, S. M.; YUYAMA, K. Atividade antagônica in vitro do óleo essencial e extrato de pimenta-longa (Pipper aduncum), no crescimento de Ralstonia solanacearum Raças 1 e 2. Fitopatologia Brasileira, Brasília, v. 13, Sup., p. 274, 2001.

VIRTUOSO, S. et al. Estudo preliminar da atividade antibacteriana das cascas de Eythrina velutina Willd., Fabaceae (Leguminosae). Revista Brasileira de Farmacognosia, João Pessoa, v. 15, n. 2, p. $137-$ $142,2005$.

WAGNER, H.; BLADT, S. Plant Drug Analysis A Thin Layer Chromatography Atlas. 2 ed. Berlin: Springer, 2009. 384 p. 